\title{
HUBUNGAN HASIL UJI SARING DARAH PADA DONOR SUKARELA DAN PENGGANTI DI RSUD ROKAN HULU
}

\author{
Erawati $^{1 *}$, Syukriadi $^{1}$ \\ Sekolah Tinggi Ilmu Kesehatan Perintis Padang \\ Jalan Adinegoro KM 17 Simpang Kalumpang Padang \\ *Email: eraayazim@gmail.com
}

\begin{abstract}
Blood transfusion is to enter blood from the donor to the recipient's circulatory system. During blood transfusions, the presence of blood that is safe from infectious diseases transmitted through blood transfusion. To ensure the safety of the blood, the UTD RSUD Rokan Hulu conducted screening tests on each donor blood with HBsAg test, anti HCV, anti TP and anti HIV. The purpose of this study was to determine the relationship between blood filter test results on voluntary donors with substitute donors in UTD RSUD Rokan Hulu in 2017. The type of this research is descriptive with a retrospective design, conducted in UTD RSUD Rokan Hulu with a population of all donors donating blood from 1 January 2017 to 31 December 2017. Univariate data were processed and analyzed which were presented in table form and bivariate data analysis was processed statistically using Chi Square test. The results showed that HBsAg was reactive at 7 voluntary donors of blood bags $(1.4 \%)$ and in donors substituting 38 blood bags (1.8\%). Anti HCV reactive in voluntary donors 0 blood bags $(0 \%)$ and in donors substituting 0 blood bags $(0 \%)$. Reactive anti-TP in voluntary donors of 10 blood bags (2.0\%) and in donors substituting 35 blood bags (1.6\%). Anti HIV reactive in voluntary donors 3 blood bags $(0.6 \%)$ and in donors substituting 3 blood bags $(0.1 \%)$. The Chi square test results showed that there was no correlation between the results of the blood screening tests at voluntary donors and substitute donors.
\end{abstract}

Keywords: Blood transfusion, Blood donor, Blood screening tests

\section{PENDAHULUAN}

Transfusi darah adalah proses memasukkan darah dari seseorang yang disebut donor ke dalam sistem peredaran darah seseorang yang lain yang disebut resipien. Transfusi darah tidak pernah dilakukan kecuali setelah ditemukan adanya sistem sirkulasi darah yang tidak pernah berhenti di dalam tubuh (Ebrahim, 2007).

Pelayanan transfusi darah merupakan upaya pelayanan kesehatan yang memanfaatkan darah manusia sebagai bahan dasar dengan tujuan kemanusiaan dan tidak untuk tujuan komersial. Pelayanan transfusi darah sebagai salah satu upaya kesehatan dalam rangka penyembuhan penyakit dan pemulihan kesehatan sangat membutuhkan ketersediaan darah atau komponen darah yang cukup, aman, mudah diakses dan terjangkau oleh masyarakat (Menteri Kesehatan RI, 2015). Darah dan produk darah memegang peranan penting dalam pelayanan kesehatan. Ketersediaan, keamanan dan kemudahan akses terhadap darah dan produk darah harus dapat dijamin. Terkait dengan hal tersebut, sesuai dengan Word health assembly (WHA) 63.12 on availability, safety and quality off blood products, bahwa kemampuan untuk mencukupi kebutuhannya sendiri atas darah dan produk darah (self sufficiency in the supply of blood and blood products) dan jaminan keamanannya merupakan salah satu tujuan pelayanan kesehatan nasional yang penting (Menteri Kesehatan RI, 2015). 
Darah dan produk-produk darah dapat menyelamatkan nyawa, namun hal ini juga dapat mengancam nyawa pasien transfusi darah karena kemungkinan menularnya infeksi dari pendonor. Darah hasil donasi sangat rentan tercemar oleh infeksi-infeksi penyakit menular. Karena itu Badan Kesehatan Dunia (WHO) pada hari kesehatan dunia tanggal 7 April tahun 2000 mencanangkan tema kampanye "darah aman berawal dari saya" (Koraag, 2010). Upaya untuk menyediakan darah yang aman sudah dimulai sejak awal, yakni pada sesi wawancara calon pendonor yang baru. Pendonor harus memberikan keterangan yang sejujurnya tentang riwayat kesehatannya. Dengan memberikan keterangan sejujurnya, akan bisa mencegah sejak dini penularan infeksi yang berbahaya melalui darah. Selanjutnya upaya pencegahan penularan infeksi penyakit dilakukan melalui uji saring di unit transfusi darah (Koraag, 2010).

Menurut (Cahyono, 2008) menyatakan bahwa salah satu risiko reaksi transfusi adalah penularan penyakit infeksi. Risiko seseorang tertular Human Immunodeficiency Virus (HIV) melalui darah yang terinfeksi mencapai $100 \%$. Sekitar $5 \%$ penderita HIV diperoleh melalui transfusi darah. Selain HIV, produk darah juga berpotensi menjadi sumber penularan virus hepatitis B, hepatitis C, sifilis dan malaria.

Risiko penularan penyakit infeksi melalui transfusi darah bergantung pada berbagai hal, antara lain prevalensi penyakit pada masyarakat, keefektifan skrining yang digunakan, status imun resipien dan jumlah donor tiap unit darah. Penularan penyakit terutama timbul pada saat window period, yaitu periode segera setelah infeksi dimana darah donor sudah infeksius tetapi hasil skrining masih negative (Yaqin, 2017).

Insidensi timbulnya hepatitis setelah transfusi darah adalah 7-10\%. Sedikitnya $90 \%$ tentang kasus ini adalah dalam kaitan dengan virus hepetitis C. Diperkirakan 5-10 \% resipien transfusi darah menunjukkan kenaikan kadar enzim transiminase yang merupakan bukti infeksi virus hepatitis. penularan hepatitis B sekitar 1:200.000 dan hepatitis C yaitu sekitar 1:10.000. Penularan HIV juga dapat terjadi melalui transfusi darah, yaitu dengan rasio 1:670.000 meski telah diupayakan penyaringan donor yang baik dan ketat (Yaqin, 2017).

Tindakan uji saring pertama pada tahap seleksi donor merupakan upaya perlindungan terhadap pendonor itu sendiri dan juga penerima donor nantinya. Setiap orang bisa menjadi pendonor dengan memenuhi persyaratan kesehatan. Persyaratan kesehatan tersebut antara lain keadaan umum calon pendonor darah tidak tampak sakit, tidak dalam pengaruh obat-obatan, memenuhi ketentuan umur, berat badan, suhu tubuh, nadi, tekanan darah, hemoglobin, ketentuan setelah haid, kehamilan dan menyusui, jarak waktu penyumbangan darah dan persyaratan lainnya meliputi keadaan kulit, riwayat transfusi darah, penyakit infeksi, riwayat imunisasi dan vaksinasi, riwayat operasi, riwayat pengobatan, obat-obat narkotika dan alkohol serta ketentuan tato, tindik, dan tusuk jarum. Selain itu perilaku hidup calon pendonor juga menjadi pertimbangan skrining awal. Yang dimaksud dengan perilaku hidup adalah kebiasaan yang berdampak buruk bagi kesehatan seperti penyalahgunaan obat dengan jarum suntik, sek bebas termasuk melakukan hubungan sek sesama jenis, dan melakukan perlukaan kulit (Astuti \& Laksono, 2013).

Uji saring Infeksi Menular Lewat Transfusi Darah (IMLTD) untuk menghindari risiko penularan infeksi dari donor kepada pasien merupakan bagian yang kritis dari proses penjaminan bahwa transfusi dilakukan dengan cara seaman mungkin. Uji saring darah terhadap infeksi paling sedikit wajib ditujukan untuk deteksi HIV, Hepatitis B, Hepatitis C dan Sifilis. Deteksi IMLTD dapat dilakukan terhadap antibodi dan atau antigen seperti metode rapid test, Enzyme Immuno Assay (EIA), Chemiluminescence Immuno Assay dan terhadap materi genetik virus seperti metoda Nucleic Acid Amplification Test (NAT) (Menteri Kesehatan RI, 2015).

Unit Transfusi Darah RSUD Rokan Hulu melakukan Uji Saring darah penyakit Infeksi Menular Lewat Tranfusi Darah menggunakan metode rapid tes, sesuai dengan kelas UTD 
Erawati. Syukriadi. 2019. Hubungan Hasil Uji Saring Darah pada Donor Sukarela dan Pengganti di RSUD Rokan Hulu. Sainstek : Jurnal Sains dan Teknologi. 11 (2): 83 - 89

RSUD Rokan Hulu yang berada pada kelas Pratama.

Penelitian yang dilakukan oleh (Ventiani, Sastri, \& Pratiwi, 2014) tentang Frekuensi HBsAg Positif pada Uji Saring Darah di Palang Merah Indonesia Cabang Padang Tahun 2012 didapatkan hasil HbsAg positif dari keseluruhan donor adalah 3,61 \%. HBsAg positif lebih banyak ditemukan pada donor sukarela yaitu sebesar 65,09 \% dari pada donor pengganti sebesar 34,91\% dari keseluruhan HbsAg yang positif.

Penelitian yang dilakukan oleh (Komalasari \& Lestari, 2015) tentang Gambaran Kateristik Pendonor, Prevalensi Infeksi HIV dan Prevalensi Infeksi Sifilis pada Pendonor Pengganti dan Pendonor Sukarela di Unit Donor Darah Provinsi Bali-RSUP Sanglah Tahun 2013 didapatkan hasil Pendonor yang tercatat di UDD PMI pada tahun 2013 sebanyak 36.486 pendonor. Pendonor tersebut terdiri dari $7.082(19,41 \%)$ pendonor pengganti dan $29.401 \quad(80,58 \%)$ pendonor sukarela. Prevalensi infeksi HIV pada pendonor sebanyak $0,27 \%$. Prevalensi infeksi HIV pada pendonor pengganti $0,28 \%$ dan pada pendonor sukarela $0,27 \%$. Prevalensi infeksi sifilis pada pendonor sebanyak $0,77 \%$. Prevalensi infeksi sifilis pada pendonor pengganti $0,89 \%$ dan pada pendonor sukarela $0,74 \%$.

Sementara itu hasil penelitian dari (Aminah, 2015) tentang HIV Reaktif Pada Calon Donor Darah di Unit Donor Darah (UDD) Pembina Palang Merah (PMI) Provinsi Lampung dan Unit Transfusi Darah PMI RSUD Pringsewu tahun 2010-2014, didapatkan hasil jumlah HIV reaktif sebanyak $0,26 \%$ dari total donor di UDD Pembina PMI Provinsi Lampung dan sebanyak $0,11 \%$ dari total donor di UTD PMI RSUD Pringsewu.

Berdasarkan uraian di atas, maka penulis tertarik untuk melakukan penelitian dengan judul "Hubungan Hasil Pemeriksaan Uji Saring Darah Pada Donor Sukarela dengan Donor Pengganti di Unit Transfusi Darah RSUD Rokan Hulu Tahun 2017”.

Tujuan penelitian ini untuk mengetahui hubungan hasil pemeriksaan uji saring darah pada donor sukarela dangan donor pengganti di
Unit Transfusi Darah RSUD Rokan Hulu pada tahun 2017.

\section{METODE PENELITIAN}

Jenis penelitian yang dilakukan adalah deskriptif dengan desain retrospektif. Penelitian dilaksakan di Unit Transfusi Darah RSUD Rokan Hulu pada bulan November 2017 Maret 2018. Populasi dan sampel dalam penelitian ini adalah semua pendonor yang menyumbangkan darahnya di Unit Transfusi Darah RSUD Rokan Hulu dari 1 Januari 2017 sampai 31 Desember 2017.

Data hasil uji saring darah yang diperoleh dianalisa secara univariat dan bivariat dengan menggunakan uji Chi Square untuk melihat hubungan hasil pemeriksaan uji saring darah pada donor sukarela dengan donor pengganti di Unit Transfusi Darah RSUD Rokan Hulu tahun 2017.

\section{HASIL DAN PEMBAHASAN}

Telah dilakukan penelitian deskriptif dengan desain retrospektif di Unit Transfusi Darah RSUD Rokan Hulu tentang hubungan hasil pemeriksaan uji saring darah pada donor sukarela dengan donor pengganti di Unit Transfusi Darah RSUD Rokan Hulu tahun 2017 dengan jumlah donor sebanyak 2.639 pendonor.

Berdasarkan Tabel 1 menunjukkan hasil donor berdasarkan umur dengan mean $38,5 \pm 12,85$, minimal umur 17 tahun dan maksimal 60 tahun. Dilihat dari jenis kelamin, lebih dari $50 \%$ berjenis kelamin laki-laki yaitu mencapai $85,2 \%$. Donor sukarela berjumlah $488(18,5 \%)$ dan donor pengganti sebanyak $2.151(81,5 \%)$. Berdasarkan hasil uji saring terhadap HBsAg menunjukkan $45 \quad(1,7 \%)$ reaktif dan $2.594(98,3 \%)$ nonreaktif. Uji saring terhadap anti $\mathrm{HCV}$ menunjukkan $0(0 \%)$ reaktif dan $2.639(100 \%)$ nonreaktif. Uji saring terhadap anti TP menunjukkan $45 \quad(1,7 \%)$ reaktif dan $2.594(98,3 \%)$ nonreaktif. Uji saring terhadap HIV menunjukkan $6(0,2 \%)$ reaktif dan $2.633(99,8 \%)$ nonreaktif. 
Erawati. Syukriadi. 2019. Hubungan Hasil Uji Saring Darah pada Donor Sukarela dan Pengganti di RSUD Rokan Hulu. Sainstek : Jurnal Sains dan Teknologi. 11 (2): 83 - 89

Tabel 1. Distribusi Donor Berdasarkan Umur, Jenis Donor, Jenis Kelamin, HBsAg, Anti HCV, Anti TP, Anti HIV

\begin{tabular}{|c|c|c|c|c|c|}
\hline Umur (tahun) & $\begin{array}{r}\text { Mean } \pm \text { SD } \\
38,5 \pm 12,85\end{array}$ & $\begin{array}{c}\text { Min } \\
17\end{array}$ & $\begin{array}{c}\operatorname{Max} \\
60\end{array}$ & $\mathrm{~F}$ & $\%$ \\
\hline \multicolumn{6}{|l|}{-Jenis kelamin } \\
\hline -Laki-laki & & & & 2.249 & 85,2 \\
\hline -Perempuan & & & & 390 & 14,8 \\
\hline \multicolumn{6}{|l|}{ Jenis Donor } \\
\hline -Donor sukarela & & & & 488 & 18,5 \\
\hline -Donor pengganti & & & & 2.151 & 81,5 \\
\hline \multicolumn{6}{|l|}{ HBsAg } \\
\hline -Reaktif & & & & 45 & 1,7 \\
\hline -Non reaktif & & & & 2.594 & 98,3 \\
\hline \multicolumn{6}{|l|}{ Anti HCV } \\
\hline -Reaktif & & & & 0 & 0 \\
\hline -Non reaktif & & & & 2.639 & 100 \\
\hline \multicolumn{6}{|l|}{ Anti TP } \\
\hline -Reaktif & & & & 45 & 1,7 \\
\hline -Non reaktif & & & & 2.594 & 98,3 \\
\hline \multicolumn{6}{|l|}{ Anti HIV } \\
\hline -Reaktif & & & & 6 & 0,2 \\
\hline -Non reaktif & & & & 2.633 & 99,8 \\
\hline
\end{tabular}

Tabel 2. Distribusi Berdasarkan Hasil Uji Saring Darah pada Donor Sukarela dengan Pengganti

\begin{tabular}{ccccc}
\hline \multirow{2}{*}{ Uji saring } & \multicolumn{4}{c}{ Pendonor } \\
\cline { 2 - 5 } & \multicolumn{2}{c}{ Sukarela } & \multicolumn{2}{c}{ Pengganti } \\
\cline { 2 - 5 } & $\mathrm{F}$ & $\%$ & $\mathrm{~F}$ & $\%$ \\
\hline HBsAg & 7 & 1,4 & 38 & 1,8 \\
$-\quad$ Reaktif & 481 & 98,6 & 2.113 & 98,2 \\
$\quad \quad$ Non reaktif & 0 & 0 & 0 & 0 \\
Anti HCV & 488 & 100 & 2.151 & 100 \\
$\quad \quad$ Reaktif & & & & \\
$-\quad$ Non reaktif & 10 & 2,0 & 35 & 1,6 \\
Anti TP & 478 & 98,0 & 2.116 & 98,4 \\
$-\quad$ Reaktif & & & & \\
$-\quad$ Non reaktif & 3 & 0,6 & 3 & 0,1 \\
Anti HIV & 485 & 99,4 & 2.148 & 99,9 \\
$-\quad$ Reaktif & & & & \\
$-\quad$ Non reaktif & &
\end{tabular}

Tabel 3. Hubungan Hasil Uji Saring Darah Pada Donor Sukarela dengan Donor Pengganti

\begin{tabular}{crrr}
\hline Jenis Donor & \multicolumn{2}{c}{ Hasil Uji Saring } & \multirow{2}{*}{ p Value } \\
\cline { 2 - 3 } Sukarela & Reaktif & Non Reaktif & \\
Pengganti & 20 & 468 & 0,3262 \\
\hline
\end{tabular}


Dari Tabel 2 menunjukkan hasil uji saring donor sukarela HBsAg reaktif sebanyak 7 (1,4\%) donor dan nonreaktif HBsAg sebanyak $481(98,6 \%)$ donor. Anti HCV reaktif $0 \quad(0 \%)$ donor dan anti HCV nonreaktif sebanyak $488(100 \%)$ donor. Anti TP reaktif sebanyak $10(2,0 \%)$ donor dan anti TP nonreaktif $478(98,0 \%)$ donor. Anti HIV reaktif sebanyak $3(0,6 \%)$ donor dan anti HIV nonreaktif sebanyak $485(99,4 \%)$ donor.

Tabel 2 menunjukkan hasil uji saring donor pengganti HBsAg reaktif sebanyak 38 $(1,8 \%)$ donor dan HBsAg nonreaktif sebanyak $2.113(98,2 \%)$ donor. Anti HCV reaktif sebanyak 0 (0\%) donor dan anti HCV nonreaktif sebanyak 2.151 (100\%). Anti TP reaktif sebanyak $35(1,6 \%)$ donor dan anti TP nonreaktif sebanyak $2.116(98,4 \%)$ donor. Anti HIV reaktif sebanyak $3(0,1 \%)$ donor dan anti HIV nonreaktif sebanyak 2.148 (99,9\%) donor.

Telah dilakukan pengolahan data hasil uji saring darah pada donor darah di Unit Tranfusi Darah RSUD Rokan Hulu tahun 2017 dengan menggunakan uji Chi Square.

Tabel 3 menunjukkan hasil uji Chi Square yang dilakukan terhadap hasil uji saring darah donor sukarela dengan donor pengganti diperoleh hasil $X^{2}$ hitung sebesar $0,3262 . X^{2}$ tabel sebesar 3,84146. Apabila $\mathrm{X}^{2}$ hitung $<\mathrm{X}^{2}$ tabel maka Ho diterima dan Ha ditolak, artinya tidak ada hubungan hasil uji saring darah pada donor sukarela dengan donor pengganti di Unit Transfusi Darah RSUD Rokan Hulu tahun 2017.

Berdasarkan data uji saring darah donor di Unit Transfusi Darah RSUD Rokan Hulu tahun 2017 didapatkan total keseluruhan uji saring yang dilakukan sebanyak 2.639 kantong darah. Pendonor darah terbagi kedalam dua jenis yaitu donor sukarela yang berjumlah 488 dan donor pengganti sebanyak 2.151. jumlah pendonor sukarela jauh lebih sedikit jika dibandingkan dengan pendonor pengganti. Hasil ini sejalan dengan penelitian yang dilakukan oleh (Aminah, 2015) mengenai jumlah pendonor di UTD RSUD Pringsewu dengan jumlah donor sukarela lebih sedikit dibandingkan dengan jumlah donor pengganti. Namun, hal tersebut berbeda dengan hasil penelitian (Wulandari, 2014) di UDD PMI provinsi Bali yang menemukan lebih banyak donor sukarela dibandingkan donor pengganti.

Hal tersebut dapat dipengaruhi oleh kesadaran masyarakat dan tempat pelaksanaan donor darah. Jumlah pendonor sukarela banyak ditemukan pada pusat yang melaksanakan donor darah di mobil unit. Selain itu rencana dan kebijakan dari pemerintah untuk meningkatkan ketersediaan darah juga dapat mempengaruhi perbedaan jumlah kelompok pendonor.

Partisipasi laki-laki dalam memberikan donor darah lebih tinggi dibandingkan perempuan. Hal tersebut sesuai dengan penelitian yang dilakukan oleh (Wulandari, 2014) yang mendapatkan partisipasi pendonor laki laki sebesar $89 \%$ dan pendonor perempuan hanya $11 \%$. Hal ini dikarenakan kriteria untuk menjadi seorang pendonor jarang dipenuhi perempuan. Misalnya kendala haid, hamil dan menyusui.

Hasil uji saring yang dilakukan pada donor sukarela yang berjumlah 488 kantong darah didapatkan hasil reaktif paling banyak pada pemeriksaan anti TP sebanyak 10 kantong $(2,0 \%)$ dan tidak ditemukan hasil reaktif pada pemeriksaan anti HCV. Sementara itu pada pemeriksaan anti HIV didapatkan hasil reaktif sebanyak 3 kantong $(0,6 \%)$ dan pada pemeriksaan $\mathrm{HBsAg}$ didapatkan hasil reaktif sebanyak 7 kantong (1,4\%). Umumnya hasil reaktif pada pendonor sukarela didapatkan pada donor pertama kali. Hal ini disebabkan oleh gaya hidup pendonor yang beresiko tertular penyakit menular dan karena pendonor tidak mengetahui kalau dirinya telah terinfeksi penyakit menular pada saat donor darah.

Uji saring yang dilakukan terhadap 2.151 kantong darah donor pengganti ditemukan hasil reaktif paling banyak pada pemeriksaan $\mathrm{HBsAg}$ sebanyak 38 kantong (1,8\%), dan kemudian pada pemeriksaan anti TP sebanyak 35 kantong $(1,6 \%)$. Pada pemeriksaan anti HIV didapatkan hasil reaktif sebanyak 3 kantong $(0,1 \%)$, namun tidak ditemukan hasil reaktif pada pemeriksaan anti HCV. Adanya hasil uji saring reaktif pada donor pengganti dapat disebabkan oleh gaya hidup pendonor yang beresiko terhadap 
penyakit menular dan ketidaktauan pendonor akan penyakit yang menginfeksi dirinya sehingga melakukan donor darah untuk keluarganya.

Hasil uji saring HBsAg pada donor sukarela dan donor pengganti yang reaktif berbeda dengan hasil penelitian yang dilakukan (Ventiani et al., 2014) dengan hasil HBsAg reaktif lebih banyak pada donor sukarela $(65,09 \%)$ dibandingkan donor pengganti $(34,91 \%)$. Hal ini dapat disebabkan karena lebih banyaknya jumlah donor pengganti daripada donor sukarela dan pendonor sukarela melakukan donor darah secara rutin sehingga pendonor sukarela yang terinfeksi tidak melakukan donor darah secara berulang.

Sementara itu hasil uji saring anti HCV pada donor sukarela dan donor pengganti yang tidak ditemukan hasil reaktif berbeda dengan hasil penelitian yang dilakukan oleh (Wulandari, 2014) yang menemukan anti HCV reaktif pada donor sukarela sebesar $0,5 \%$ dan pada donor pengganti $0,2 \%$. Hal ini dapat dipengaruhi masa untuk terbentuknya antibodi HCV memerlukan waktu 4 sampai 24 minggu, sehingga pada saat pendonor mendonorkan darah pada masa window period masih mendapatkan hasil nonreaktif.

Untuk hasil uji saring anti TP di dapatkan hasil reaktif pada donor sukarela $(2,0 \%)$ lebih tinggi dari donor pengganti $(1,6 \%)$. Hasil ini berbeda dengan hasil penelitian yang dilakukan oleh (Komalasari \& Lestari, 2015) dengan hasil sifilis reaktif lebih tinggi pada pendonor pengganti $(0,89 \%)$ dibandingkan dengan pendonor sukarela $(0,74 \%)$. Hasil tersebut dapat di pengaruhi karena perbedaan jumlah antara kelompok donor pengganti dengan donor sukarela.

Uji saring yang dilakukan terhadap anti HIV menunjukkan lebih banyak hasil reaktif pada donor sukarela sebesar $0,6 \%$ dan donor pengganti sebesar $0,1 \%$. Hasil tersebut berbeda dengan hasil penelitian yang dilakukan oleh (Komalasari \& Lestari, 2015) yang mendapatkan hasil anti HIV reaktif lebih banyak pada donor pengganti sebesar 0,28\% dibandingkan hasil pada donor sukarela sebesar $0,27 \%$.
Adanya perbedaan hasil penelitian yang dilakukan dengan penelitian yang telah dilakukan sebelumnya dapat disebabkan oleh perbedaan jumlah pendonor yang mendonorkan darah, baik pendonor sukarela maupun donor pengganti.

Berdasarkan hasil uji Chi Square yang dilakukan pada pengujian data hasil uji saring pada donor sukarela dengan donor pengganti didapatkan hasil tidak ada hubungan hasil uji saring darah pada donor sukarela dengan donor pengganti dengan $\mathrm{X}^{2}$ hitung sebesr 0,3262 dan $\mathrm{X}^{2}$ tabel sebesar 3,84146, artinya hasil pemeriksaan uji saring darah tidak ada hubungannya dengan jenis donor darah. Donor sukarela atau donor pengganti sama sama berpotensi untuk mendapatkan hasil reaktif atau non reaktif.

\section{KESIMPULAN}

Dari hasil penelitian hubungan hasil pemeriksaan uji saring darah pada donor sukarela dengan donor pengganti di Unit Transfusi Darah RSUD Rokan Hulu tahun 2017, maka dapat diambil kesimpulan sebagai berikut :

Jumlah HBsAg reaktif pada donor sukarela sebanyak 7 kantong darah atau 1,4\% dari total donor sukarela dan jumlah HBsAg reaktif pada donor pengganti sebanyak 38 kantong darah atau $1,8 \%$ dari total donor pengganti. Jumlah anti HCV reaktif pada donor sukarela sebanyak 0 kantong darah atau $0 \%$ dari total donor sukarela dan jumlah anti $\mathrm{HCV}$ reaktif pada donor pengganti sebanyak 0 kantong darah atau $0 \%$ dari total donor pengganti.

Jumlah anti TP reaktif pada donor sukarela sebanyak 10 kantong darah atau 2,0\% dari total donor sukarela dan jumlah anti TP reaktif pada donor pengganti sebanyak 35 kantong darah atau $1,6 \%$ dari total donor pengganti. Jumlah anti HIV reaktif pada donor sukarela sebanyak 3 kantong darah atau $0,6 \%$ dari total donor sukarela dan jumlah anti HIV reaktif pada donor pengganti sebanyak 3 kantong darah atau $0,1 \%$ dari total donor 
pengganti. Tidak ada hubungan hasil uji saring darah pada donor sukarela dengan donor pengganti di Unit Tranfusi Darah RSUD Rokan Hulu dengan $\mathrm{X}^{2}$ hitung sebesar 0,3262 < $\mathrm{X}^{2}$ tabel sebesar 3,84146, maka $\mathrm{H}_{0}$ diterima dan $\mathrm{Ha}$ ditolak.

\section{DAFTAR KEPUSTAKAAN}

Aminah, S. (2015). HIV Reaktif pada Calon Donor Darah di Unit Donor Darah (UDD) Pembina Palang Merah Indonesia (PMI) Provinsi Lampung dan Unit Transfusi Darah PMI RSUD Pringsewu tahun 2010 - 2014. Jurnal Analis Kesehatan, 4(2), 427-435.

Astuti, W. D., \& Laksono, A. D. (2013). Keamanan Darah Di Indonesia Potret Keamanan Transfusi Darah di Daerah Tertinggal, Perbatasan dan Kepulauan. Surabaya: Health Advocacy.

Cahyono, S. B. (2008). Membangun Budaya Keselamatan Pasien dalam Praktik Kedokteran. Yogyakarta: Kanisius.

Ebrahim, A. F. M. (2007). Fikih Kesehatan, Kloning, Eutanasia, Tranfusi Darah, Transpalasi Organ, dan Eksperimen pada Hewan. Jakarta: PT Serambi Ilmu Semesta.
Komalasari, N. L. G. Y., \& Lestari, A. A. W. D. (2015). Gambaran Karakteristik Pendonor, Prevalensi Infeksi Hiv, dan Prevalensi Infeksi Sifilis pada Pendonor Pengganti dan Pendonor. Jurnal Fakultas Keokteran Universitas Udayana, 4(11).

Koraag, J. F. (2010). Berbagi Nyawa, Hidup Bahagia dengan Berdonor Darah. Yogyakarta: Pustaka Marwa.

Menteri Kesehatan RI. (2015). Peraturan Menteri kesehatan Republik Indonesia Nomor 91 tahun 2015 tentang Standar Pelayanan Tranfusi Darah. Jakarta.

Ventiani, N., Sastri, S., \& Pratiwi, D. (2014). Frekuensi HBsAg Positif pada Uji Saring Darah di Palang Merah Indonesia Cabang Padang Tahun 2012. Jurnal Kesehatan Andalas, 3(1), 924-927.

Wulandari, P. M. (2014). Gambaran Hasil Skrining Hepatitis B dan Hepatitis C pada Darah Donor di Unit Donor Darah PMI Provinsi Bali. Universitas Udayana Denpasar.

Yaqin, A. A. (2017). Transfusi Darah. Retrieved from https://www.academia.edu/10329743/TR ANSFUSI_DARAH 